\title{
Systematic review on treatment of juvenile idiopathic arthritis - associated uveitis
}

\author{
Arnd Heiligenhaus \\ From 21st European Pediatric Rheumatology (PReS) Congress \\ Belgrade, Serbia. 17-21 September 2014
}

\section{Background}

Juvenile idiopathic arthritis (JIA) is commonly complicated by chronic uveitis that frequently leads to visual loss.

\section{Methods}

Review of the current literature on the treatment of JIA associated uveitis.

\section{Results}

Therapy of JIA-associated uveitis is guided by the severity of inflammation and complications. Topical corticosteroids are generally used as the initial treatment. Severe uveitis is commonly treated with immunosuppressive drugs. Methotrexate is presently the first-choice agent. If uveitis is not responding, another immunosuppressive agent or biological is applied. Currently, adalimumab is the preferred TNF-inhibitor. In refractory disease, other biologicals are used (e.g., rituximab, tocilizumab or abatacept). Ocular corticosteroid injections / - implantations are considered as "rescue therapy".

\section{Conclusions}

Controlled studies are warranted to offer most effective and safe therapy for children with JIA - associated uveitis. Better knowledge of the basic mechanisms underlying the disease and of the molecules that are important for regulating inflammation may help to create new and more specific treatment approaches, and to improve disease monitoring.

\section{Disclosure of interest}

None declared.

Published: 17 September 2014

Ophthalmology, St Franziskus Hospital, Muenster, Germany
doi:10.1186/1546-0096-12-S1-16

Cite this article as: Heiligenhaus: Systematic review on treatment of juvenile idiopathic arthritis - associated uveitis. Pediatric Rheumatology 2014 12(Suppl 1):16.
Submit your next manuscript to BioMed Central and take full advantage of:

- Convenient online submission

- Thorough peer review

- No space constraints or color figure charges

- Immediate publication on acceptance

- Inclusion in PubMed, CAS, Scopus and Google Scholar

- Research which is freely available for redistribution

Submit your manuscript at www.biomedcentral.com/submit
C Bïomed Central
() Biomed Central

(C) 2014 Heiligenhaus; licensee BioMed Central Ltd. This is an Open Access article distributed under the terms of the Creative Commons Attribution License (http://creativecommons.org/licenses/by/4.0), which permits unrestricted use, distribution, and reproduction in any medium, provided the original work is properly cited. The Creative Commons Public Domain Dedication waiver (http://creativecommons.org/publicdomain/zero/1.0/) applies to the data made available in this article, unless otherwise stated. 